\title{
Colonic epithelial cell proliferation in hereditary non-polyposis colorectal cancer
}

\author{
S E Green, P Chapman, J Burn, A D Burt, M Bennett, D R Appleton, J S Varma, \\ J C Mathers
}

Department of

Surgery, University of Newcastle upon Tyne, UK

S E Green

J S Varma

Department of Human Genetics, University of Newcastle upon Tyne,

UK

J Burn

P Chapman

Department of

Statistics, University of Newcastle upon Tyne, UK

D R Appleton

Department of

Biological and

Nutritional Sciences,

University of

Newcastle-upon-Tyne

J C Mathers

Department of Pathology, Royal Victoria Infirmary, Newcastle-upon-Tyne, UK

A D Burt

M K Bennett

Correspondence to: Miss S E Green, 43A Leazes Terrace, Newcastle upon Tyne NE1 4CZ, UK

Accepted for publication 19 January 1998

\begin{abstract}
Background-Despite the recent discovery of four genes responsible for up to $90 \%$ of all cases of hereditary non-polyposis colorectal cancer (HNPCC), there will still be families in whom predictive testing is not possible. A phenotypic biomarker would therefore be useful. An upwards shift of the proliferative compartment in colonic crypts is reported to be one of the earliest changes in premalignant mucosa. Aims-To assess the role of crypt cell proliferation as a phenotypic biomarker in HNPCC.
\end{abstract}

Patients-Thirty five patients at $50 \%$ risk of carrying the HNPCC gene (21 of whom subsequently underwent predictive testing and hence gene carrier status was known) and 18 controls.

Methods-Crypt cell proliferation was measured at five sites in the colon using two different techniques. Labelling index was determined using the monoclonal antibody MIB1 and whole crypt mitotic index was measured using the microdissection and crypt squash technique. The distribution of proliferating cells within the crypts was also assessed.

Results-There were no significant differences in the total labelling index or mean number of mitoses per crypt, nor in the distribution of proliferating cells within the crypt, between the study and control groups at any site. When the 21 patients in whom gene carrier status was known were analysed separately there were no significant differences in the measured indices of proliferation between the HNPCC gene carriers and non-gene carriers.

Conclusion-Crypt cell proliferation is not a discriminative marker of gene carriage in HNPCC.

(Gut 1998;43:85-92)

Keywords: cell proliferation; hereditary non-polyposis colorectal cancer

In normal colonic mucosa the proliferative compartment is confined to the lower half to two thirds of the crypt. It has been suggested that one of the earliest changes in premalignant mucosa may be an extension of the proliferative compartment towards the luminal surface. ${ }^{1}$ Lipkin reported extension of the proliferative zone in the flat mucosa of patients with isolated adenomatous polyps, familial adenomatous polyposis (FAP), and "hereditary precancerous disease" using autoradiographic techniques. ${ }^{1}$
Other workers have subsequently reported similar findings in patients with sporadic adenomatous polyps, colorectal cancers, and FAP..$^{2-14}$ These studies suggested that the whole of the colonic mucosa expresses proliferative abnormalities - that is, there is a field change rather than a focal change..$^{814-16}$

Hereditary non-polyposis colorectal cancer (HNPCC) is an autosomal dominant condition characterised by the development of colorectal cancer at an early age (mean age 44 years), an excess of synchronous and metachronous tumours, and a preponderance $(70 \%)$ of right sided tumours. ${ }^{17}$ Unlike FAP, HNPCC gene carriers have no phenotypic features, so identification of probands has relied on the accurate documentation of family histories. Colorectal cancers in HNPCC develop from benign adenomatous polyps but the progression to malignancy seems to be much more rapid than in sporadic cancers. ${ }^{18}$ This is due to a germline mutation in one or more of several DNA mismatch repair genes. Four genes involved in mismatch repair have recently been identified. ${ }^{19-22}$ hMSH2 and hMLH1 are thought to account for $70-90 \%$ of all cases of HNPCC. hPMS1 and hPMS2, together with possibly other as yet unidentified DNA mismatch repair genes, will probably account for the remainder. ${ }^{23}$ As families will remain in whom linkage analysis proves unsuccessful or in whom a mutation cannot be identified, a phenotypic biomarker would be a useful adjunct in risk assessment.

Early studies in patients with a germline mutation of one of the mismatch repair genes suggested that in order for tumorigenesis to occur a second mutation was probably required to inactivate the normal wild type allele. Parsons et al showed that lymphoblastoid cells from an HNPCC patient, whose colorectal cancer showed multiple replication errors, were repair proficient. ${ }^{24}$ More recently, however, Parsons et al have looked again at the non-neoplastic cells of patients with HNPCC for mismatch repair defects using more sensitive methods. ${ }^{25}$ They found evidence of microsatellite instability in non-neoplastic cells in a subset of patients with HNPCC. They postulated that this may be due to inherited mutations of other genes that participate in mismatch repair, with multiple germline mutations leading to a reduction of mismatch repair activity. An alternative hypothesis is that mismatch repair gene mutations are acting in a "dominant negative" fashion; the product of the abnormal allele interferes with the function of the normal protein. If this is the case 
mutations could accumulate in the "normal" colonic mucosa in patients with HNPCC. This may trigger apoptosis, as a means of protecting the tissue, which would lead to increased cell loss. To maintain normal tissue homoeostasis, this increased cell loss by apoptosis could, in turn, lead to an increase in cell proliferation.

This study investigated the role of crypt cell proliferation as a phenotypic biomarker in HNPCC. Crypt cell proliferation was measured in random colonic biopsy specimens from known HNPCC family members who had an affected first degree relative and thus a $50 \%$ chance of having inherited the HNPCC gene. Gene carrier status became known in some of these individuals enabling comparison of the results between known gene carriers and known non-gene carriers. The control group comprised symptomatic individuals who were referred for colonoscopy but were found to have endoscopically and histologically normal colonic mucosa and a clinical diagnosis of nonspecific abdominal pain or irritable bowel syndrome.

\section{Methods}

SUBJECTS AND COLLECTION OF BIOPSY SPECIMENS Thirty five patients (mean age 43.9 years, range 17-71 years) from four well documented HNPCC families were studied. All were asymptomatic and had macroscopically and histologically normal colonic mucosa. The majority of individuals in this group were from two large HNPCC pedigrees in whom the mutations have been identified recently. ${ }^{26} 27$ The remaining patients came from two smaller pedigrees, both fulfilling the Amsterdam criteria, ${ }^{28}$ but neither of whom have, as yet, undergone linkage studies or mutation analysis. Hence no data were available on their gene status. There were 18 patients in the control group (mean age 52.2 years, range $21-80$ ).

All colonoscopies were performed using either an Olympus CF IT200L or Olympus CF IT20L videoscope, between 900 am and 300 pm. The bowel preparation was standardised (one sachet of sodium picosulphate (Picolax) in the morning and a further sachet in the late afternoon on the day before colonoscopy). Two mucosal biopsy specimens were taken at colonoscopy, from each of five sites along the length of the colon (ascending, transverse, descending, sigmoid, and rectum). The biopsy specimens were spread out flat on cellulose acetate paper, mucosal side up, and then fixed immediately, one in formalin for MIB1 staining and one in Carnoy's fluid for microdissection. The latter samples were transferred to $70 \%$ ethanol for storage.

ASSESSMENT OF CRYPT CELL PROLIFERATION Two techniques were used to assess crypt cell proliferation: immunohistochemistry using the monoclonal antibody MIB1, ${ }^{29}{ }^{30}$ and microdissection and mitosis counting in whole crypts. ${ }^{31}$

\section{MIB1}

The biopsy specimens for MIB1 immunohistochemistry were fixed overnight prior to dehydration, embedding, and sectioning. They were dewaxed, rehydrated, and endogenous peroxidase activity was blocked using methanol and hydrogen peroxide. The slides were then placed in sodium citrate buffer at $\mathrm{pH} 6.0$ in a $750 \mathrm{~W}$ domestic microwave oven for $2 \times 5 \mathrm{~min}-$ utes, to unmask the antigenic sites. An indirect immunoperoxidase technique was employed using a streptavidin-biotin-peroxidase complex. The peroxidase activity was developed with diaminobenzadine (DAB) prior to counterstaining with haematoxylin. Negative controls were prepared in exactly the same way but the primary antibody was omitted. Each biopsy specimen was viewed under a compound light microscope and optimally sectioned hemicrypts, visible from base to luminal surface, were counted using the $\times 40$ objective lens. The number of labelled cells per hemicrypt and the total number of cells per hemicrypt were recorded. The labelling index per hemicrypt (LI) was then calculated (number of labelled cells per total number of cells). There was no significant difference in the mean number of cells per hemicrypt in the HNPCC group and the control group (78 (0.82) and 76 (1.0), respectively). Each crypt was also divided into five equal compartments, from base (compartment 1) to luminal surface (compartment 5), using an eye piece graticule, and the LI per compartment was also recorded. Ten crypts were counted per intestinal site.

\section{Microdissection and mitosis counting}

For microdissection and mitosis counting the biopsy specimens were rehydrated in $50 \%$ ethanol for 10 minutes, followed by $25 \%$ ethanol for 10 minutes. They were then hydrolysed in $1 \mathrm{M} \mathrm{HCl}$ at $60^{\circ} \mathrm{C}$ for seven minutes. The tissue was stained using the Feulgen reaction by placing in Schiff's reagent for 45 minutes; the tissue turned a deep magenta colour. ${ }^{31} \mathrm{~A}$ portion of the stained tissue was placed on a microscope slide, covered with a drop of $45 \%$ acetic acid, and placed under a dissecting microscope. Two 20 gauge needles, mounted on $1 \mathrm{ml}$ insulin syringes, were used to tease apart the tissue, separating out clumps of two to three crypts. A coverslip was then gently placed over the tissue to help separate the crypts. The number of mitoses per crypt was counted, using a compound light microscope and a $\times 40$ objective lens, by racking up and down through the field. Strict criteria were applied to define mitoses, counting only distinct late prophases, metaphases, anaphases, and early telophases. Ten crypts were counted per biopsy specimen and the mean number of mitoses per crypt was recorded. Again, each crypt was divided into five equal compartments by length and the mean number of mitoses per compartment was recorded.

\section{STATISTICAL ANALYSES}

Data were analysed using the Minitab statistical package, version $9.2 .^{32}$

Comparison of the two techniques

The two techniques used to measure cell proliferation, MIB1 and microdissection and mitosis counting, were compared by plotting 


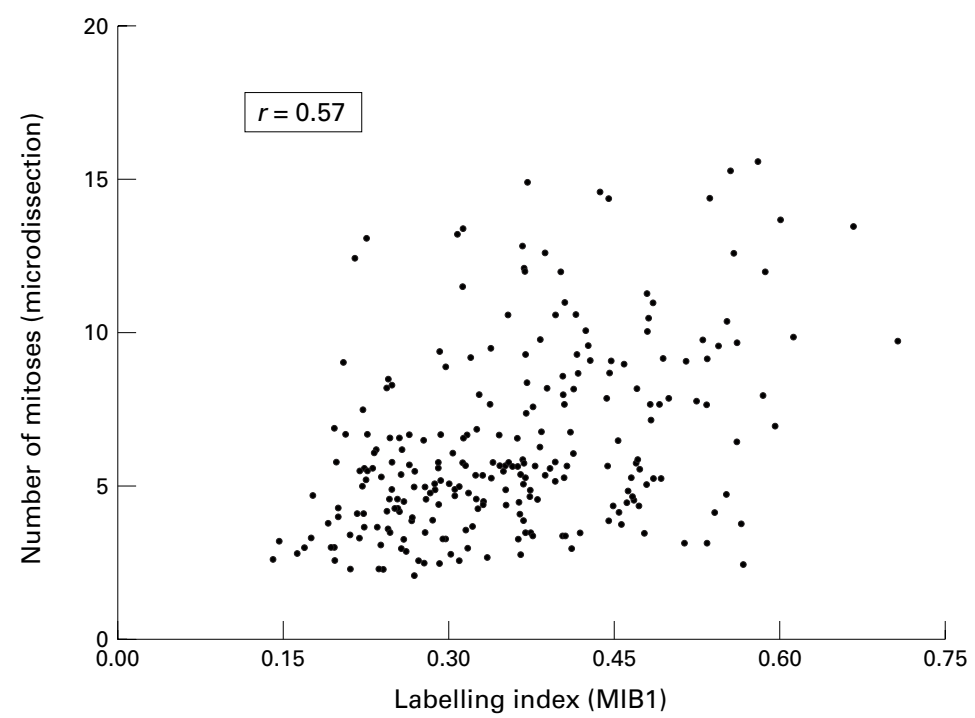

Figure 1 Comparison of the MIB1 labelling index with the mean number of mitoses per crypt (265 points plotted represent data for 53 patients from five sites).

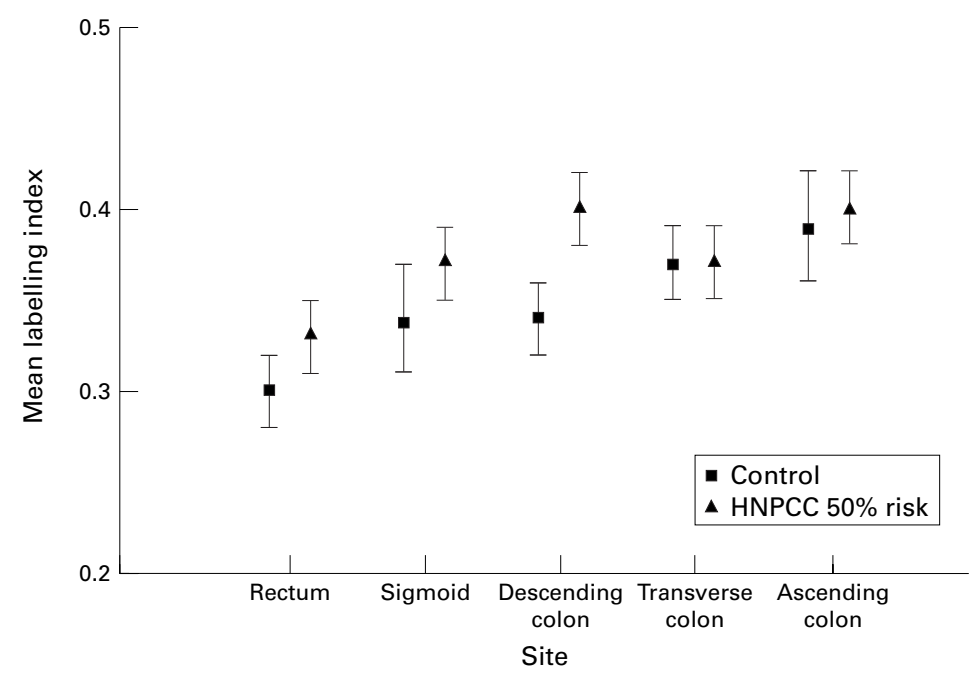

Figure 2 MIB1 data-changes in the labelling index along the large bowel for the HNPCC 50\% risk group and control group.

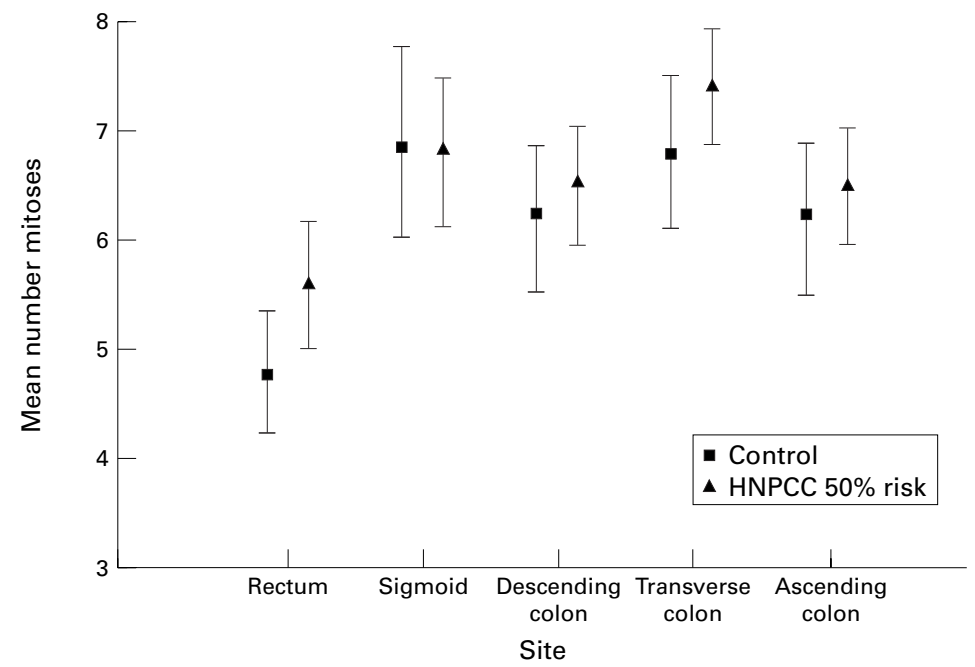

Figure 3 Microdissection data-changes in the mean number of mitoses per crypt along the large bowel for the HNPCC 50\% risk group and control group. the MIB1 LI against number of mitoses per crypt and calculating the correlation coefficient.

Differences in cell proliferation according to site and patient group

Overall analysis of variance was performed for the control and HNPCC 50\% risk groups considering all sites. Site was considered as a covariate in this analysis, allowing for the order of the sites throughout the colon and rectum.

Differences in cell proliferation at individual sites according to patient group

Further analysis on patient groups was performed for the individual sites, again using analysis of variance, as there were significant differences in proliferation indices between the five sites (see Results). This was performed for both the total labelling indices and the compartmental labelling indices. It has been emphasised, by other workers, that it is the upper $40 \%$ of the crypt that is important in detecting compartmental shifts in at risk individuals; $\mathrm{s}^{5}$ therefore, for the purpose of analysis, compartments 1, 2, and 3 were grouped together and compartments 4 and 5 together.

A $p$ value of less than 0.05 was considered significant but where analysis was repeated for each of the five sites, $p<0.01$ was considered a significant result, to minimise the problems associated with repeated significance testing.

Differences in cell proliferation according to gene carrier status

Within the HNPCC $50 \%$ risk group a separate analysis was performed on total and compartmental proliferation indices according to gene carrier status and individual sites. The same method of analysis was used as above, except that gene status was considered instead of patient group.

\section{Results}

COMPARISON OF THE TWO TECHNIQUES

Comparison of the MIB1 LI and number of mitoses per crypt showed a highly significant correlation between the two techniques although there was wide variation $(r=0.57$, $\mathrm{p}<0.0001$ ) (fig 1).

DIFFERENCES IN CELL PROLIFERATION ACCORDING TO SITE AND PATIENT GROUP MIB1

When both patient groups were considered together there was a highly significant linear trend across the five colonic sites $(p=0.001)$, with the mean LI being greatest in the ascending colon and lowest in the rectum (fig 2). Having adjusted for this variation between intestinal sites, the difference in LI between the HNPCC $50 \%$ risk group and control group was not significant $(\mathrm{p}=0.06)$.

Microdissection and mitosis counting

When both patient groups were considered together, there was again a significant linear trend across the five colonic sites $(p=0.02)$ with the mean number of mitoses being lowest 
Table 1 Mean LI (total) and mean number of mitoses per crypt for the control group and HNPCC 50\% risk group at each of the five sites

\begin{tabular}{|c|c|c|c|c|c|c|}
\hline \multirow[b]{2}{*}{ Site } & \multicolumn{2}{|l|}{ Controls } & \multicolumn{2}{|c|}{ HNPCC $50 \%$ risk } & \multicolumn{2}{|l|}{$p$ Value ${ }^{\star}$} \\
\hline & Mean LI & Mean no of mitoses & Mean LI & Mean no of mitoses & Mean LI & Mean no of mitoses \\
\hline Rectum & $0.30(0.02)$ & $4.8(0.56)$ & $0.33(0.02)$ & $5.6(0.59)$ & 0.31 & 0.40 \\
\hline Sigmoid & $0.34(0.03)$ & $6.9(0.88)$ & $0.37(0.02)$ & $6.8(0.68)$ & 0.39 & 0.98 \\
\hline Descending colon & $0.34(0.02)$ & $6.2(0.67)$ & $0.40(0.02)$ & $6.5(0.55)$ & 0.07 & 0.75 \\
\hline Transverse colon & $0.37(0.02)$ & $6.8(0.70)$ & $0.37(0.02)$ & $7.4(0.53)$ & 0.81 & 0.48 \\
\hline Ascending colon & $0.39(0.03)$ & $6.2(0.70)$ & $0.40(0.02)$ & $6.5(0.53)$ & 0.77 & 0.73 \\
\hline
\end{tabular}

Results are expressed as mean (SEM).

${ }^{\star}$ Controls $v$ HNPCC $50 \%$ risk. Due to concern related to repeated significance testing, $\mathrm{p}>0.01$ was considered non-significant.

Table 2 Mean compartmental LI and number of mitoses (compartments 1, 2, and 3) for the control group and the HNPCC $50 \%$ risk group at each of the five sites

\begin{tabular}{|c|c|c|c|c|c|c|}
\hline \multirow[b]{2}{*}{ Site } & \multicolumn{2}{|l|}{ Controls } & \multicolumn{2}{|c|}{ HNPCC $50 \%$ risk } & \multicolumn{2}{|l|}{$p$ Value ${ }^{\star}$} \\
\hline & Mean LI & Mean no of mitoses & Mean LI & Mean no of mitoses & Mean LI & Mean no of mitoses \\
\hline Rectum & $1.15(0.10)$ & $4.5(0.49)$ & $1.25(0.08)$ & $5.1(0.50)$ & 0.45 & 0.40 \\
\hline Sigmoid & $1.36(0.11)$ & $6.6(0.78)$ & $1.45(0.08)$ & $6.4(0.59)$ & 0.49 & 0.91 \\
\hline Descending colon & $1.63(0.07)$ & $5.9(0.64)$ & $1.78(0.07)$ & $6.1(0.53)$ & 0.17 & 0.83 \\
\hline Transverse colon & $1.27(0.06)$ & $5.9(0.53)$ & $1.51(0.07)$ & $5.9(0.44)$ & 0.06 & 0.98 \\
\hline Ascending colon & $1.45(0.12)$ & $6.3(0.63)$ & $1.59(0.08)$ & $6.9(0.49)$ & 0.35 & 0.52 \\
\hline
\end{tabular}

Results are expressed as mean (SEM).

${ }^{\star}$ Controls $v$ HNPCC $50 \%$ risk. Due to concern related to repeated significance testing, $\mathrm{p}>0.01$ was considered non-significant.

in the rectum (fig 3). Having adjusted for this variation between sites there were no significant differences in the mean number of mitoses per crypt between the HNPCC 50\% risk group and control group $(\mathrm{p}=0.51)$, in agreement with the MIB1 data.

DIFFERENCES IN CELL PROLIFERATION ACCORDING TO PATIENT GROUP AT THE INDIVIDUAL SITES Mean total MIB1 LI and mean number of mitoses per crypt

The mean total LI and the mean number of mitoses per crypt at the individual sites tended to be greater in the HNPCC 50\% risk group compared with the control group (table 1) but these differences were not significant.

Compartmental MIB1 LI and mean number of mitoses per compartment at the individual sites There were no significant differences in the mean labelling index or mean number of mitoses in the lower $60 \%$ of the crypt (compartments 1, 2, and 3) between the
HNPCC $50 \%$ risk group and control group at any site (table 2). Likewise there were no significant differences in the mean LI or mean number of mitoses in the upper $40 \%$ of the crypt (compartments 4 and 5) between the HNPCC $50 \%$ risk group and control group at any site (table 3), although again there was a tendency for higher values in the HNPCC 50\% risk group.

DIFFERENCES IN CELL PROLIFERATION ACCORDING TO GENE CARRIER STATUS AT THE INDIVIDUAL SITES

Mean total MIB1 LI and mean total number of mitoses per crypt

Within the HNPCC $50 \%$ risk group gene carrier status was known in 21 of 35 patients. Overall analysis of variance adjusting for any variation due to site showed no significant difference in the total mean LI or mean number of mitoses between gene carriers and non-gene carriers $(p=0.13$ and $p=0.08$ respectively). There were also no significant

Table 3 Mean compartmental LI and number of mitoses (compartments 4 and 5) for the control group and the HNPCC $50 \%$ risk group at each of the five sites

\begin{tabular}{|c|c|c|c|c|c|c|}
\hline \multirow[b]{2}{*}{ Site } & \multicolumn{2}{|l|}{ Controls } & \multicolumn{2}{|c|}{ HNPCC $50 \%$ risk } & \multicolumn{2}{|l|}{$p$ Value $^{\star}$} \\
\hline & Mean LI & Mean no of mitoses & Mean LI & Mean no of mitoses & Mean LI & Mean no of mitoses \\
\hline Rectum & $0.10(0.02)$ & $0.34(0.10)$ & $0.16(0.03)$ & $0.43(0.13)$ & 0.28 & 0.61 \\
\hline Sigmoid & $0.12(0.04)$ & $0.31(0.12)$ & $0.16(0.03)$ & $0.32(0.10)$ & 0.54 & 0.92 \\
\hline Descending colon & $0.12(0.03)$ & $0.31(0.07)$ & $0.18(0.03)$ & $0.41(0.08)$ & 0.25 & 0.37 \\
\hline Transverse colon & $0.13(0.03)$ & $0.34(0.13)$ & $0.16(0.03)$ & $0.34(0.08)$ & 0.46 & 0.99 \\
\hline Ascending colon & $0.15(0.04)$ & $0.43(0.10)$ & $0.25(0.03)$ & $0.48(0.08)$ & 0.05 & 0.71 \\
\hline
\end{tabular}

Results are expressed as mean (SEM).

${ }^{\star}$ Controls $v$ HNPCC $50 \%$ risk. Due to concern related to repeated significance testing, $\mathrm{p}>0.01$ was considered non-significant.

Table 4 Mean total LI and number of mitoses per crypt for known gene carriers and known non-gene carriers

\begin{tabular}{|c|c|c|c|c|c|c|}
\hline \multirow[b]{2}{*}{ Site } & \multicolumn{2}{|l|}{ Controls } & \multicolumn{2}{|c|}{ HNPCC $50 \%$ risk } & \multicolumn{2}{|l|}{$p$ Value ${ }^{\star}$} \\
\hline & Mean LI & Mean no of mitoses & Mean LI & Mean no of mitoses & Mean LI & Mean no of mitoses \\
\hline Rectum & $0.33(0.05)$ & $5.7(1.20)$ & $0.33(0.04)$ & $4.6(0.66)$ & 0.97 & 0.36 \\
\hline Sigmoid & $0.32(0.03)$ & $7.9(2.17)$ & $0.38(0.05)$ & $5.8(0.77)$ & 0.38 & 0.33 \\
\hline Descending colon & $0.36(0.04)$ & $7.1(1.30)$ & $0.41(0.04)$ & $5.9(0.87)$ & 0.45 & 0.45 \\
\hline Transverse colon & $0.34(0.04)$ & $7.0(1.34)$ & $0.39(0.04)$ & $5.5(0.60)$ & 0.40 & 0.29 \\
\hline Ascending colon & $0.38(0.04)$ & $7.0(0.89)$ & $0.43(0.04)$ & $7.0(0.93)$ & 0.44 & 0.97 \\
\hline
\end{tabular}

Results are expressed as mean (SEM).

${ }^{\star}$ Controls $v$ HNPCC $50 \%$ risk. Due to concern related to repeated significance testing, $\mathrm{p}>0.01$ was considered non-significant. 


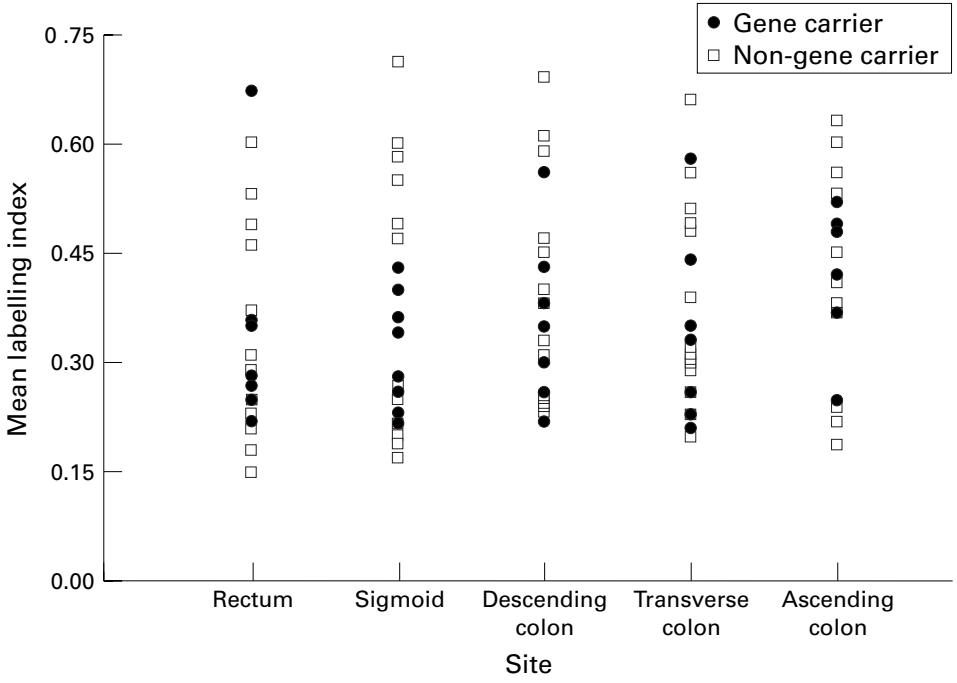

Figure 4 Mean labelling index for all five sites, according to gene carrier status.

differences in the mean total LI or mean number of mitoses at the individual sites between those who had inherited the mutation and those who had not (table 4, fig 4).

Mean compartmental LI and mean number of mitoses per compartment at the individual sites The mean compartmental LIs and mean number of mitoses for the lower $60 \%$ of the crypt (compartments 1, 2, and 3) were similar in those who had inherited the mutation and those who did not carry the mutation (table 5). The mean compartmental LIs in the upper $40 \%$ of the crypt (compartments 4 and 5) were also similar in the gene carriers and non-gene carriers (table 6 ). In the upper $40 \%$ of the crypt the mean number of mitoses tended to be greater in the gene carriers compared with the non-gene carriers (table 6) but these differences were not significant.

\section{Discussion}

Many criticisms have been levelled at cell kinetic studies because of methodological flaws. ${ }^{33-35}$ To minimise this problem two different techniques were used in this study. MIB1 is rapidly gaining favour as a robust marker of cell proliferation and is superseding the use of $\mathrm{Ki}-67$, which can only be used on snap frozen or fresh tissue. ${ }^{29}{ }^{36}$ Microdissection and mitosis counting overcomes some of the criticisms levelled at all immunohistochemical techniquesfor example, concomitant changes in the denominator and pitfalls associated with scoring crypt sections. ${ }^{33}$

As the two techniques used in this study identify cells during different parts of the cell cycle (MIB1-throughout the cell cycle; microdissection $-M$ phase only) and results for each are expressed on different bases, the absolute values obtained are obviously different. However, comparison of the two techniques showed a significant correlation between MIB1 and microdissection and mitosis counting but with considerable variation for individual biopsy specimens. Potential sources of variability are proliferation assay reproducibility, variation in biopsy site, and potential artefacts caused, for example, by some bowel preparations. ${ }^{37}$ For the MIB1 proliferation assay reproducibility was determined by multiple counts on the same biopsy specimens. Differences between average counts for MIB1 were $1.8-4 \%$. In assessing variability between counts for microdissection and mitosis counting a fresh set of crypts had to be prepared; thus variations in counting would be confounded by true biological variations. Hence variability between counts for microdissection and mitosis counting was greater $(7-16 \%)$.

Some variation may also occur between biopsy specimens taken from the same region of the colon but at a slightly different site. Alberts and Einspahr showed small differences

Table 5 Mean compartmental LI and number of mitoses (compartments 1, 2, and 3) for known gene carriers and known non-gene carriers at each of the five sites

\begin{tabular}{|c|c|c|c|c|c|c|}
\hline \multirow[b]{2}{*}{ Site } & \multicolumn{2}{|l|}{ Controls } & \multicolumn{2}{|c|}{ HNPCC $50 \%$ risk } & \multicolumn{2}{|l|}{$p$ Value $^{\star}$} \\
\hline & Mean LI & Mean no of mitoses & Mean LI & Mean no of mitoses & Mean LI & Mean no of mitoses \\
\hline Rectum & $1.26(0.17)$ & $5.1(0.82)$ & $1.29(0.16)$ & $4.3(0.62)$ & 0.93 & 0.45 \\
\hline Sigmoid & $1.27(0.11)$ & $7.2(1.90)$ & $1.47(0.20)$ & $5.7(0.78)$ & 0.48 & 0.44 \\
\hline Descending colon & $1.64(0.12)$ & $6.6(1.32)$ & $1.80(0.15)$ & $5.8(0.88)$ & 0.46 & 0.60 \\
\hline Transverse colon & $1.34(0.15)$ & $6.4(1.24)$ & $1.57(0.14)$ & $5.3(0.59)$ & 0.30 & 0.39 \\
\hline Ascending colon & $1.49(0.15)$ & $6.5(0.79)$ & $1.68(0.16)$ & $6.5(0.89)$ & 0.42 & 0.99 \\
\hline
\end{tabular}

Results are expressed as mean (SEM).

${ }^{\star}$ Controls $v$ HNPCC $50 \%$ risk. Due to concern related to repeated significance testing, $\mathrm{p}>0.01$ was considered non-significant.

Table 6 Mean compartmental LI and number of mitoses (compartments 4 and 5) for known gene carriers and known non-gene carriers at each of the five sites

\begin{tabular}{|c|c|c|c|c|c|c|}
\hline \multirow[b]{2}{*}{ Site } & \multicolumn{2}{|l|}{ Controls } & \multicolumn{2}{|c|}{ HNPCC $50 \%$ risk } & \multicolumn{2}{|l|}{$p$ Value ${ }^{\star}$} \\
\hline & Mean LI & Mean no of mitoses & Mean LI & Mean no of mitoses & Mean LI & Mean no of mitoses \\
\hline Rectum & $0.24(0.11)$ & $0.68(0.38)$ & $0.12(0.05)$ & $0.27(0.14)$ & 0.27 & 0.27 \\
\hline Sigmoid & $0.14(0.05)$ & $0.70(0.34)$ & $0.17(0.34)$ & $0.06(0.02)$ & 0.75 & 0.04 \\
\hline Descending colon & $0.15(0.07)$ & $0.48(0.17)$ & $0.19(0.07)$ & $0.12(0.04)$ & 0.72 & 0.03 \\
\hline Transverse colon & $0.20(0.08)$ & $0.59(0.22)$ & $0.16(0.05)$ & $0.19(0.06)$ & 0.64 & 0.06 \\
\hline Ascending colon & $0.26(0.04)$ & $0.51(0.18)$ & $0.24(0.05)$ & $0.33(0.12)$ & 0.80 & 0.37 \\
\hline
\end{tabular}

Results are expressed as mean (SEM).

${ }^{\star}$ Controls $v$ HNPCC $50 \%$ risk. Due to concern related to repeated significance testing, $\mathrm{p}>0.01$ was considered non-significant. 
in mean LIs taken at the same level in the rectum but from four different quadrants. ${ }^{37}$ Several studies have examined the effect of different bowel preparations on crypt cell proliferation..$^{38}$ All showed that the standard bowel preparations, as used in this present study, have no significant effect on crypt cell proliferation although enemas may induce an increase in cell proliferation due to exfoliation of cells from the mucosal surface. All patients in this study received the same regime to avoid any such artefactual variation.

The majority of human studies using proliferative indices as a marker for neoplastic risk have looked at rectal epithelial proliferation only, or have not stated the site from which biopsy specimens were taken. This may not accurately reflect the picture elsewhere in the colon. In this study proliferation was studied at five sites along the colon. Previous studies of differences in proliferative indices at different sites in the human large bowel have yielded inconsistent observations. ${ }^{40-46}$ The significant reduction in both the MIB1 LI and mean number of mitoses per crypt as one moves caudally along the colon, shown in this study, underlines the importance of stating the site from which biopsy specimens are taken for comparative studies and illustrates a potential source of error in previous studies on colonic crypt cell proliferation.

The indices of crypt cell proliferation used in this study showed no significant differences in the total mean LI or the mean number of mitoses per crypt between the HNPCC 50\% risk and control groups. This is in agreement with previous studies both in patients with sporadic colorectal adenomas or carcinomas and patients at risk of HNPCC. ${ }^{6-8} 4748$

There was no significant difference in the distribution of proliferating cells within crypts between the HNPCC 50\% risk and control groups. This is in contrast to the majority of previous studies in patients with sporadic adenomas or carcinomas and patients at risk of HNPCC, which have reported a shift of the proliferative compartment towards the luminal surface..$^{2-14}$ The reasons for this divergence in results are not clear although, as already discussed, they all used a single techniqueeither autoradiography following the incorporation of tritiated thymidine or immunohistochemistry using a monoclonal antibody-to measure proliferation and some were performed on rectal biopsy specimens alone. Three studies have been published in which no shift of the proliferative compartment in patients with sporadic adenomas and carcinomas compared with controls was reported. The first is that of Matthew et al in which the distribution of proliferating cells (studied using the microdissection and crypt squash technique) was not significantly different in patients with adenomatous polyps compared with controls. ${ }^{49}$ Secondly Kashtan et al compared the thymidine labelling index and spatial distribution of rectal mitoses of adenoma patients with controls but no differences could be detected. ${ }^{50}$ Finally Nakamura et al examined the labelling distribution of colonic crypts using ex vivo autoradiography. ${ }^{51}$ They studied patients with sporadic colonic adenomas, sporadic adenocarcinomas, and patients with FAP. They found similar labelling distributions and an absence of upwards shift of the active proliferating zone in all three groups. They went on to support their findings by investigating the nuclear DNA content in the lower two thirds and upper third of isolated crypts from the same patients. The results showed that all nuclei in the upper one third of crypts had a normal diploid DNA content in both FAP and sporadic colorectal cancer, indicating that none of these cells was proliferating. ${ }^{52}$

In the present study gene carrier status was known in 21 of 35 at risk patients and this group was examined separately. Analysis of variance showed no significant difference in either the total LI, compartmental LI, total number of mitoses, or distribution of mitoses in this group compared with those who had not inherited the gene. Only one other published study has looked at crypt cell proliferation in known HNPCC gene carriers..$^{53}$ All other studies have looked at individuals "at risk" of having inherited the genetic mutation. This means that twice as many patients would be needed to show any difference as $50 \%$ of those studied would be normal (that is, not carry the HNPCC gene). In this study Jass et al reported no difference in either the labelling indices or proliferative compartment locations between the mutation positive patients and a control group. ${ }^{53}$ Their numbers, however, were small $(n=4)$ and they lacked a proper control group. Their control group consisted of individuals with a history of colorectal cancer but lacking the clinical and pathological features of HNPCC.

$\mathrm{Jass}^{54}$ had previously questioned the model of Fearon and Vogelstein which proposes a stage of hyperproliferation preceding neoplastic initiation. ${ }^{55} \mathrm{He}$ has suggested that focal hyperproliferation is synonymous with microadenoma and indeed identified a focal lesion composed of dysplastic tubules in the illustrations from which Fearon and Vogelstein developed their model of the adenoma-carcinoma sequence. Vogelstein has now replaced "hyperproliferation" with "dysplastic aberrant crypt foci" in this model of colorectal tumorigenesis. ${ }^{56}$ Recent evidence also suggests that in HNPCC there is no increase in the somatic mutation rate in the normal mucosa, ${ }^{57} 58$ but that the HNPCC gene defect acts at the level of the adenoma to promote tumour progression, ${ }^{535}$ unlike the APC gene in FAP which affects the rate of tumour initiation. This negates the proposed preneoplastic stage of mucosal hyperproliferation throughout the colon and supports the findings in this study.

The proposed link between cell proliferation and susceptibility to colorectal cancer is further questioned by the differences in the background proliferation indices in different regions of the intestinal tract ${ }^{42}{ }^{59}$; cancers occur more frequently in those segments with a relatively low LI. In this study there was an increased LI in both patient groups in the right colon compared with the sigmoid colon and rectum, where $60 \%$ of all colorectal cancers 
arise. Potten et al also reported a higher LI in the ileum and colon compared with the rectum, but from the duration of $S$ phase they were able to calculate the turnover time, which was greater in the rectum. ${ }^{42}$ The longer the tissue turnover time the greater the duration of exposure to possible luminal carcinogens, which may contribute to the increased incidence of sporadic cancers in the distal colon compared with the proximal colon.

Crypt cell proliferation is known to be affected by a wide variety of factors including diet, drugs, age, bowel preparation, and circadian rhythm. ${ }^{60-66}$ Methodological variations are also likely to occur even if strict criteria are adhered to. Expansion of the proliferative compartment within normal flat colorectal mucosa described by others may well, therefore, be a reflection of a non-specific response to a variety of luminal factors or flawed methodological techniques, rather than a precursor of malignancy.

1 Lipkin M. Phase 1 and phase 2 proliferative lesions of colonic epithelial cells in diseases leading to colonic cancer. Cancer 1974;34:878-88.

2 Bleiberg H, Buyse M, Galand P. Cell kinetic indicators of premalignant stages of colorectal cancer. Cancer 1985;56: $124-9$.

3 Deschner E, Winawer SJ, Long FC, et al. Early detection of colonic neoplasia in patients at high risk. Cancer 1977;40: $2625-31$

4 Deschner E, Maskens AP. Significance of the labelling index and labelling distribution as kinetic parameters in colorectal mucosa of pation

5 Lipkin M, Blattner WE, Fraumeni JF, et al. Tritiated thymidine labelling distribution as a marker for hereditary predisposition to colon cancer. Cancer Res 1983;43:1899904.

6 Maskins AP, Deschner E. Tritiated thymidine incorporation into epithelial cells of normal appearing colorectal mucosa of cancer patients. F Natl Cancer Inst 1977;58:1221-4.

7 Paganelli GM, Biasco G, Santucci R, et al. Rectal cell proliferation and colorectal cancer risk level in patients with non-familial adenomatous polyps of the large bowel. Cancer 1991;68:2451-4.

8 Ponz de Leon M, Roncucci L, Donato P-Di, et al. Pattern of epithelial cell proliferation in colorectal mucosa of normal subjects and of patients with adenomatous polyps or cancer of the large bowel. Cancer Res 1988;48:4121-6.

9 Risio M, Lipkin M, Candelaresi GL, et al. Correlations between rectal cell proliferation and the clinical and pathobetween rectal cell proliferation and the clinical and patho-
logical features of nonfamilial neoplasia of the large

10 Risio M, Candelaresi G, Rossini FP. Bromodeoxyuridine uptake and proliferating cell nuclear antigen expression throughout the colorectal tumour sequence. Cancer Epidemiology Biomarkers and Prevention 1993;2:363-7.

11 Roncucci L, Scalmati A, Ponz de Leon M. Pattern of cell kinetics in colorectal mucosa of patients with different types of adenomatous polyps of the large bowel. Cancer 1991;68:873-8

12 Saunders MP, Jourdan MH, Filipe MI, et al. Cell proliferation studies to define patients at increased risk of colorectal cancer [abstract]. Br f Surg 1992;79:460.

13 Mills SJ, Shepherd NA, Hall PA, et al. Proliferative compartment deregulation in the non-neoplastic colonic epithelium of familial adenomatous polyposis. Gut 1995; 36:391-4.

14 Terpstra OT, Blankenstein M, van Dees J, et al. Abnormal pattern of cell proliferation in the entire colonic mucosa of patients with colon adenoma or cancer. Gastroenterology 1987;92:704-8.

15 Deschner EE, Godbold J, Lynch HT. Rectal epithelial cell proliferation in a group of young adults. Cancer 1988;61 2286-90.

16 O'Brien MJ, O'Keane JC, Zauber A, et al. Precursors of colorectal carcinoma. Biopsy and biologic markers [review]. Cancer. 1992;70(5,Suppl.):1317-27.

17 Lynch HT, Lanspa SJ, Boman BM, et al. Hereditary nonpolyposis colorectal cancer-Lynch syndromes I and II. Gastroenterol Clin North Am 1988;17:679-712.

18 Jass JR, Stewart S.M. Evolution of hereditary non-polyposis colorectal cancer. Gut 1992;33:783-6.

19 Fishel R, Lescoe MK, Rao MRS, et al. The human mutator gene homolog MSH2 and its association with hereditary nonpolyposis colon cancer. Cell. 1993;75:1027-38.

20 Leach FS, Nicolaides NC, Papadopoulos N, et al. Mutations of a mutS homolog in hereditary nonpolyposis colorectal of a mutS homolog in hereditar

21 Bronner CE, Baker SM, Morrison PT, et al. Mutation in the DNA mismatch repair gene homologue hMLH2 is associ- ated with hereditary non-polyposis colorectal cancer. Nature 1994;368:258-61.

22 Lindblom A, Tannergard P, Werelius B, et al. Genetic mapping of a second locus predisposing to hereditary non-polyposis colorectal cancer. Nat Genet 1993;5:279-82.

23 Nicolaides NC, Papadopoulos N, Liu B, et al. Mutations in two PMS homologues in hereditary nonpolyposis colon cancer. Nature 1994;371:75-80.

24 Parsons R, Li G-M, Longley MJ, et al. Hypermutability and mismatch repair deficiency in RER+ tumour cells. Cell 1993;75:1227-36

25 Parsons R, Li G-M, Longley M, et al. Mismatch repair deficiency in phenotypically normal human cells. Science 1995 ; 268:738-40.

26 Kolodner RD, Hall NR, Lipford J, et al. Structure of the human MSH2 locus and analysis of two Muir-Torre kindreds for msh2 mutations. Genomics 1994;24:516-26.

27 Hall NR, Williams MAT, Murday VA, et al. Muir-Torre syndrome: a variant of the cancer family syndrome. $f \mathrm{Med}$ Genet 1994;31:627-31.

28 Vasen HF, Mecklin J-P, Meera Khan P, et al. The international collaborative group on hereditary noninternational collaborative group on hereditary non-

29 Key G, Becker MHG, Baron B, et al. New Ki-67-equivalent murine monoclonal antibodies (MIB1-3) generated against bacterially expressed parts of the Ki-67 cDNA containing three 62 base pair repetitive elements encoding for the Ki-67 epitope. Lab Invest 1993;68:629-36.

30 Cattoretti G, Becker MHG, Key G, et al. Monoclonal antibodies against recombinant parts of the KI-67 antigen (MIB1 and MIB3) detect proliferating cells in microwaveprocessed formalin-fixed paraffin sections. F Pathol 1992; 168:357-63.

31 Goodlad RA, Levi S, Lee CY, et al. Morphometry and cell proliferation in endoscopic biopsies: evaluation of a technique. Gastroenterology 1991;101:1235-41.

32 Minitab Inc. Minitab statistical package, version 9.2. State College, PA 16801-3008.

33 Goodlad RA. Microdissection-based techniques for the determination of cell proliferation in gastrointestinal epithelium: application to animal and human studies. In: Cell biology: a laboratory handbook. London: Academic Press, 1993.

34 Risio M. Methodological aspects of using immunohistochemical cell proliferation biomarkers in colorectal carcinoma chemoprevention. If Cell Biochem 1994; (suppl 19):61-7.

35 Maurer HR. Potential pitfalls of $\left[{ }^{3} \mathrm{H}\right]$ thymidine techniques to measure cell proliferation. Cell Tissue Kinetics 1981;14: $111-20$

36 McCormick D, Chong H, Hobbs C, et al. Detection of the $\mathrm{KI}-67$ antigen in fixed and wax-embedded sections with the monoclonal antibody MIB1. Histopathology 1993;22: 335-60.

37 Alberts DS, Einspahr J. Validation of proliferation indices as surrogate endpoint biomarkers. F Cell Biochem 1994; (suppl 19):76-83.

38 Fireman Z, Pozen P, Fine N, et al. Reproducibility studies and effects of bowel preparations on the measurements of rectal epithelial proliferation. Cancer Lett 1989;45:59-64.

39 Lynch PM, Wargovich MJ, Lynch HT, et al. A follow-up study of colonic epithelial proliferation as a biomarker in a native-American family with hereditary nonpolyposis colon cancer. F Natl Cancer Inst 1991;83:951-4.

40 O'Sullivan KR, Mathias PM, Beattie S, et al. The effect of colonic site of biopsy on cell proliferation profiles using BRDU incorporation as a measure of cell proliferation. Eur f Cancer Prev 1992;1:381-3.

41 Potten CS, Kellett M, Roberts SA, et al. Measurement of in vivo proliferation in human colorectal mucosa using bromodeoxyuridine. Gut 1992;33:71-8.

42 Potten CS, Kellett M, Rew DA, et al. Proliferation in human gastrointestinal epithelium using bromodeoxyuridine in vivo: data for different sites, proximity to tumour, and polyposis coli. Gut 1992;33:524-9.

43 Cats A, De Vries EGE, Kleibeuker JH. Proliferation rate in hereditary non-polyposis colon cancer. $\mathcal{F}$ Natl Cancer Inst 1991;83:1687-8.

44 Cats A, de Vries EGE, Zwart N, et al. Epithelial proliferation in different segments of the colon in hereditary nonpolyposis colon cancer (HNPCC) [abstract]. Gastroenterology 1992;102:A348.

45 Terpstra OT, Blankenstein M, van Dees J, et al. Abnormal pattern of cell proliferation in the entire colonic mucosa of patients with colon adenoma or cancer. Gastroenterology 1987;92:704-8.

46 Ponz de Leon M, Roncucci L, Donato P-Di, et al. Pattern of epithelial cell proliferation in colorectal mucosa of normal subjects and of patients with adenomatous polyps or cancer of the large bowel. Cancer Res 1988;48:4121-6.

47 Deschner EE, Godbold J, Lynch HT. Rectal epithelial cell proliferation in a group of young adults. Cancer 1988;61: 2286-90.

48 Markowitz JF, Aiges HW, Cunningham-Rundles S, et al. Family syndrome: marker studies. Gastroenterology 1986; 91:581-9.

49 Matthew JA, Pell JDP, Prior A, et al. Validation of a simple technique for the detection of abnormal mucosal cell replication in humans. Eur F Cancer Prev 1994;3:337-44.

cation in humans. Eur f Cancer Prev 1994;3:337-44.
50 Kashtan H, Stern HS, Jenkins DJA, et al. Colonic fermentation and markers of colorectal cancer risk. Am f Clin Nutr 1992;55:723-8 
51 Nakamura S, Kino I, Baba S. Cell kinetic analysis of background colonic mucosa of patients with intestinal neo-
plasms by ex vivo autoradiography. Gut 1988;29:997plasms

52 Nakamura S, Kino I, Baba S. Nuclear DNA content of isolated crypts of background colonic mucosa from patients with familial adenomatous polyposis and sporadic colorectal cancer. Gut 1993;34:1240-4.

53 Jass JR. Failure to detect colonic mucosal hyperproliferation in mutation positive members of a family with hereditary non-polyposis colorectal cancer. Histopathology 1997;30: 201-7.

54 Jass JR. Colorectal adenoma progression and genetic change: is there a link? Ann Med 1995;27:301-6.

55 Fearon ER, Vogelstein B. A genetic model for colorectal tumorigenesis. Cell 1990;61:759-67.

56 Kinzler KE, Vogelstein B. Lessons from hereditary colorectal cancer. Cell 1996;87:159-70.

57 Jass JR, Edgar S. Unicryptal loss of heterozygosity in hereditary non-polyposis colorectal cancer. Pathology 1994;26: tary non-
$414-17$.

58 Williams GT, Geraghty JM. Normal colonic mucosa in hereditary non-polyposis colorectal cancer shows no generalised increase in somatic mutation. $\mathrm{Br} \mathcal{F}$ Cance 1995;71:1077-80.

59 Hall C, Youngs D, Keighley MRB. Crypt cell production rates at various sites around the colon in Wistar rats and humans. Gut 1992;33:1528-31.
60 Lehy T, Abitbol JL, Mignon M. Influence de la preparation rectale par lavement sur la proliferation cellulaire dans la muquese rectale normale de l'homme. Gastroenterol Clin Biol 1984;8:216-20.

61 Fireman Z, Rozen P, Fine N, et al. Influence of demographic arameters on rectal epithelial proliferation. Cancer Lett 1989;47:133-40.

62 Kennedy MFG, Tutton PMJ, Barkla DH. Comparison of the circadian variation in cell proliferation in normal and neoplastic colonic epithelial cells. Cancer Lett 1985;28:16975.

63 Sigdestad CP, Bauman J, Lesher S. Diurnal fluctuations in the numbers of cells in mitosis and DNA synthesis in the jejunum of the mouse. Exp Cell Res 1969;58: $159-62$.

64 Bayer BM, Beaven MA. Evidence that indomethacin reversbly inhibits cell growth in the G1 phase of the cycle. Biochem Pharmacol 1979;28:441-3.

65 Logan RFA, Little J, Hawtin PG, et al. Effect of aspirin and non-steroidal anti-inflammatory drugs on colorectal adenomas: case-control study of subjects participating in the Nottingham faecal occult blood screening programme. BMF 1993;301:285-8.

66 Key FB, McClean D, Mathers JC. Tissue hypertrophy and epithelial proliferation rate in the gut of rats fed on bread and haricot beans (Phaseolus vulgaris). Br F Nutr 1996;76: 273-86. 